\title{
Asymmetric Effect of Monetary Policy in Emerging Countries: The Case of Egypt
}

\author{
Mamdouh Abdelmoula M. Abdelsalam \\ Correspondence: Mamdouh Abdelmoula M. Abdelsalam, Department of Economics, Menoufia University, Egypt. \\ E-mail: mamdouh.abd@commerce.menofia.edu.eg; mamdmohamed@yahoo.com
}

Received: March 8, 2018

Accepted: April 23, $2018 \quad$ Available online: May 2, 2018

doi:10.11114/aef.v5i4.3090

URL: https://doi.org/10.11114/aef.v5i4.3090

\begin{abstract}
The aim of this study is to explore the asymmetric effect of the unanticipated monetary policy shocks on inflation and real production. This is done by utilizing the non-linear autoregressive distributed lag (ARDL) model. Nonlinear ARDL allows us to check for the asymmetric effect of the policy in terms of the size of the shocks: large or small, and the stance of the shocks: loose or tight. Additionally, Wald test is employed to confirm the underlying relationship. The results provided a sufficient evidence for the idea of the asymmetric effect of monetary policy in Egypt. Firstly, regarding the size of the policy, only small shocks have a considerable effect on both inflation and real production. Secondly, regarding the direction of the policy, only positive shocks have a considerable influence on both variables. Wald test confirmed the abovementioned results. Therefore, based on these results, the monetary policy in Egypt is only effective under some circumstances and thus other economic policies such as fiscal policy might be more effective in these cases.
\end{abstract}

Keywords: monetary policy, econometric modeling, asymmetric policy, non-linear ARDL, monetary policy shocks JEL Classification: E52, C1, C5.

\section{Introduction}

It is well accepted in the economic literature that monetary policy can affect inflation and real production during the short run. However, there is an ongoing debate with respect to the asymmetric impact of monetary decisions. The second issue is a critical point for policymakers because decisions which assuming symmetric effects of the policy might not give the targeted results.

There are many theoretical justifications for the asymmetric effect of monetary policy. Firstly, attitudes of borrowers and lenders under different monetary conditions are not the same. When the central bank raises its policy rate and then consequently market rates should be raised by the banks. However, banks can raise interest rates only for specific level as expanding the interest rate could increase the likelihood of risk default of borrowers. On the other side, when the monetary authority declines its interest rate, there is no guarantee that private borrowing and spending will increase. The latter could be dampening by the economic conditions. Secondly, in the context of the standard New-Keynesian theoretical structure which assumes a supply curve is flexible and convex, the monetary actions are neutral in the case of negative shocks and are non-neutral in the case of positive shocks (see: Cover, 1992). Credit restrict models imply that tight monetary policy causes banks to become more cautious about giving money and thus they will try raising interest rates. Thus, a tight policy characterized by strong credit demand might be more appropriate on many occasions (Morgan 1993). Another evidence comes from the menu cost models, where higher levels of inflation encourage firms to adjust their prices of final products where lower levels do not give firms enough incentive to change the prices of their products.

Empirically, since the great depression in 1929, there are suspensions about tight monetary policy has a more significant effect than expansionary policy as the Fed could not succeed in alleviating the recession effect of the crash (Friedman and Schwartz,1963). Recently, whereas the US contractionary monetary policy successfully achieved its target: declining inflation during the period from 1888 to 1889 , the US expansionary policy could not achieve its target: stimulating GDP growth in the 1990s. Similarly, although the Japanese central bank achieved its goals with contraction 
policy, it could not stimulate real production by adopting an expansionary policy in 1990. Lastly, during the recent great recession in 2008, Fed moved to using unconventional monetary policy after cutting its policy rate to around zero percent.

Usually, it is being assumed that the central bank loss function is quadratic in real production and inflation and then it minimizes this function with the assumption of the linear environment of the economy. However, the central bank seems to treat positive and negative deviations differently. Also, some empirical studies examined the asymmetric effect of monetary actions regarding the size of shocks. Ravn and Sola (1996) support that only small shocks have a significant effect. In addition, Aye and Gupta (2012) explore the asymmetric effect of central bank actions in terms of the state of the economy.

Implications of the asymmetric impact of policy actions might be crucial regarding conducting this policy and estimated costs of the monetary shocks on supply and demand. Also, augmenting of the asymmetric components inside the monetary authority's reaction equation could induce better understanding of the behavior of this policy. This could give better predictions and help in improving the modeling process of monetary decisions. Central banks might adopt asymmetric preferences; we can find some banks face real production fluctuations with accepting high inflation volatilities. The aversion for those banks might be greater towards recession than expansion. Adversely, other monetary authorities might care more about inflation stabilization (recently, the number of this category increased after the decision of many central banks on behalf of adoption inflation targeting regime). Cukierman and Muscatelii (2008) divide central banks into Inflation Avoidance Preferences (IAP) and Recession Avoidance Preferences (RAP). The first group banks consider more positive inflation gaps, while the second group banks care more about negative output gaps. This asymmetric preference produces nonlinear reaction functions. Cukierman and Muscatelii (2008) give evidence that LAP leads to convex Taylor rule while RAP leads to concave Taylor rule. Similarly, the supply curve could suffer from nonlinearity. Many empirical works conclude that in the case of the negative output gap, the impact of monetary policy on inflation is limited, whereas in the case of positive output gap its impact is positive and significant (Laxton et al. 1999 and Pyhtia 1999). Furthermore, the likely uncertainty associated with productivity growth rate could cause the policy to be nonlinear (Dolado et al. 2004). Some of today works, which mainly focus on developed countries, explore asymmetric effects on the selected macro variables. The last issue is critical for policymakers; the existence of asymmetric impact in the effect of policy shocks might reflect that monetary actions are not valid and other policies such as fiscal policy might be more suitable. However, the most substantial portion around this important point is for developed countries. In the case of Egypt, there are no such studies and it is still unexplored empirical area. Subsequently, this research tries to capture the asymmetry in the decisions of the central bank of Egypt by utilizing nonlinear ARDL model initiated by Shin et al. (2014). Nonlinear ARDL can help in decomposing policy shocks into increasing and decreasing shocks regarding directions and into small and big shocks regarding the size. The contributions of this paper are many. Firstly, to our knowledge, there are no previous studies explored this important issue for Egypt and then this paper will be up to date unique. Secondly, it depicts the unanticipated monetary policy shocks from the most common form of Taylor rule. Thirdly, it utilizes both linear and nonlinear forms. Fourthly, we explore for the asymmetry over both the short run and the long run.

Results can be summarized as follows. Firstly, in regard to the asymmetric of policy direction, we conclude only significant effect on real production and inflation for positive shocks; the negative shocks do not have any significant impact. Secondly, in regard to the asymmetric of policy size, we conclude only significant effect for small shocks; the big shocks do not have any significant impact.

The study is divided into five sections. After the introduction, we present the previous literature in the section number two. The third section covers the adopted model and the methodology. The fourth section reports data and empirical results. Lastly, in the fifth section, we conclude and give some policy recommendations.

\section{Literature Review}

The answer to the question in what extent the effect of monetary policy is asymmetric has attracted many empirical kinds of literature. Whereas the theoretical effect of monetary policy is based on some assumptions such as nominal rigidities and asymmetric available information, expansionary and contractionary monetary policy gives different consequences when nominal prices or nominal wages are rigid in the direction of downward but they are flexible in the direction of upward. Further, the models which adopt the cost of menu imply that firms hold prices fixed after small changes in production cost in order to avoid paying the burden of menu changes. Thus, small monetary policy shocks are non-neutral, but big monetary policy shocks are neutral. Moreover, the classical theories consider the case of monetary neutralization as the fundamental case. Indeed, monetary policy can affect the nominal aggregates such as inflation but it cannot affect the real side. Similarly, various studies indicate that the effect of the monetary policy on the real production is asymmetric (Cover, 1992).

Empirical studies explored the asymmetry in monetary shocks can be classified into two different sides; the stance of 
shocks (positive or negative) and the size of the shocks (small or big change). Barro (1978) explains the effect of unanticipated and anticipated innovations on the production inside rational expectation environment. He states only unanticipated shocks can effect on production. Cover (1992), Karras and Stokes (1996) and (1999) claim that only negative unanticipated monetary policy shocks have a considerable effect on GDP. Rhee and Rich (1995) argue there is no evidence about the asymmetry of Fed during the post-world war II period. Karras et al. (1996) employ the maximum likelihood estimation method on data of eighteen European countries during the period 1953 to 1999. They find that the effect of negative shocks is more significant than positive. Ravn and Sola (1997) conclude that small shocks have a significant effect on macro variables where the big ones do not affect (in the case of using money supply as a monetary policy tool). When they used the interest rate as an instrument, they support the idea of asymmetric effect in terms of the stance and the size of the policy. Paul (1998) examines the asymmetric effect of the unexpected interest rate shocks for the UK. He supports the asymmetry in terms of the policy direction. Volker Clausen \& Bernd Hayo (2003) build a semi-structural framework to analyze the asymmetric effect of monetary policy transmission mechanism for some European countries. The developed dynamic system includes simultaneously three equations to represent monetary policy reaction function, output gap and inflation. The study finds asymmetries in the effects of output gap on inflation and also on the effect of real interest rate.

Other empirical works consider the likely nonlinearity in the asymmetry of central banks' actions. Weise (1999) utilizes a logistic smooth transition vector autoregressive structure in order to explore the asymmetric effect of monetary policy actions. Philip M. Bodman (2006) uses a simple threshold model to examine both the anticipated and the unanticipated effect of monetary policy for Australia. The paper finds an asymmetric effect for both positive and negative unanticipated shocks; only positive unanticipated shocks significantly raise GDP. Regis \& Christian (2014) measure the non-linear effects of monetary policy based on non-linear impulse response functions. They conclude that the effects of monetary policy depend on some factors such as the sign and the level of the policy shocks. However, this works only if the size of the change is enormous. Volkan and Hakan (2015) use the innovative nonlinear VAR that was built by Kilian and Vigfusson (2011) for exploring the likely asymmetry in the effect of central bank decisions on Turkish output, prices, and the value of the domestic currency. They conclude that positive monetary policy shocks negatively affect output, inflation and exchange rate. However, the effect of positive socks is stronger than that negative. Moreover, the big shocks have a more significant effect than negative ones. Cheng Jiang (2018) concludes that the effect of monetary policy on the stock market is asymmetric over different levels of the stock market index.

Some studies consider factors that might affect the asymmetric effect of monetary policy shocks. Mustafa Caglayan et al. (2017) examine the impact of the developments of the financial markets in the asymmetry of the Fed shocks. They support that financial deepening contributes to increasing the effectiveness of monetary policy during a recession. Sensier et al. (2002) find the decisions of central banks are more effective during times of recession. Dolado and Mar'ia-Dolores (2006) capture the different effects of policy shocks over varied states of the economy. Vlieghe, G. (2017) examines the risk associated the asymmetric impact of zero monetary policy rates. Moreover, Midrigan and Xu (2014) and Maurice Obstfeld (2018) state that the asymmetric effect of monetary policy might lead to diffusion in the level of a marginal product of capital across different firms.

Regarding emerging and developing countries, few works explored the asymmetric effect of monetary policy and the results also are heterogeneous. Pierre-Richard (2001) explores the asymmetry in central bank shocks on inflation, GDP and the real value of the domestic currency by using Vector Autoregressive (VAR) models in a group of four developing countries; Turkey, Malaysia, Korea, and the Philippines. The impulse response results show that monetary policy innovations have asymmetric effects which vary across countries and instruments. Vid (2002) examines the asymmetric effect of government expenditures and money supply for Indonesia. However, he does not capture an evidence to support his assumptions. By utilizing annual series from 1973 to 2008, Akbar Komijani et al. (2012) explore the asymmetry in the response of inflation and GDP to the shocks of the amount of available money in Iran. They find that inflation is significantly affected by positive shocks where the output is significantly affected by negative shocks. Akl and Abdelsalam (2017) conclude that the relationship between interest rate and expected inflation for Egypt is nonlinear. Abdelsalam (2017) finds the Philips curve for Egypt is nonlinear and Time-varying. Olumuyiwa Apanisile (2017) does not support the asymmetric effect of money supply on the output of Nigeria. Jeevan Kumar Khundrakpam (2017) states that monetary policy shocks have an asymmetric effect on aggregate demand of India. Felix S. Nyumuah (2018) confirms the idea of the asymmetric preferences for central bank regarding the real production for some developing countries.

\section{Model and Methodology}

This paper employs an approach which is analogous to that used by (Cover, 1992; Morgan, 1993; Shen, 2000). The utilized approach includes two main steps: In the first step, the common Taylor rule is estimated in order to generate both anticipated and unanticipated shocks. In the second step, the impact of unanticipated shocks on target variables 
(inflation and real production) is modeled by using NARDL for Shin et al. (2014).

\subsection{Interest Rate Equation and the Linear Form}

The identification of the reaction function of the interest rate by utilizing ARDL model proposed by Pesaran et al. (2011) is given as follows:

$$
\begin{gathered}
\Delta i_{t}=\alpha+\alpha_{1} i_{t-1}+\alpha_{2} X_{t-1}+\alpha_{3} I N F_{t-1}+\alpha_{4} e x_{t-1}+\sum_{k=1}^{p} \beta_{1 k} \Delta i_{t-k}+\sum_{k=1}^{p} \beta_{2 k} \Delta X_{t-k}+\sum_{k=1}^{p} \beta_{3 k} \Delta I N F_{t-k}+ \\
\sum_{k=1}^{p} \beta_{4 k} \Delta e x_{t-k}+\varepsilon_{t}
\end{gathered}
$$

Where $i_{t}$ is the interest rate at time $\mathrm{t}, X_{t}$ is the growth in real production, $I N F_{t}$ is annual inflation rate, ex $x_{t}$ is the real exchange rate.

Then, the unanticipated monetary policy shocks can be expressed as:

$$
\begin{gathered}
\varepsilon_{t}=\Delta i_{t}-\left[\alpha+\alpha_{1} i_{t-1}+\alpha_{2} X_{t-1}+\alpha_{3} I N F_{t-1}+\alpha_{4} e x_{t-1}+\sum_{k=1}^{p} \beta_{1 k} \Delta i_{t-k}+\sum_{k=1}^{p} \beta_{2 k} \Delta X_{t-k}+\sum_{k=1}^{p} \beta_{3 k} \Delta I N F_{t-k}+\right. \\
\left.\sum_{k=1}^{p} \beta_{4 k} \Delta e x_{t-k}\right]
\end{gathered}
$$

Where, $\alpha_{j}$ are the coefficients of long run relationship and while $\beta_{j k}$ are the coefficients of short run variables included in equation number (2).

With the aim of testing the effect of shocks on inflation and GDP, we can model the relationship in the form of ARDL as following:

$$
\Delta Y_{t}=\Theta+\Theta_{1} Y_{t-1}+\Theta_{2} \varepsilon_{t-1}+\sum_{k=1}^{p} \omega_{1 k} \Delta Y_{t-k}+\sum_{k=1}^{p} \omega_{2 k} \Delta \varepsilon_{t-k}+u_{t}
$$

Where $Y_{t}$ expresses monetary policy goals; $X_{t}$ and $I N F_{t}$.

\subsection{Testing for Asymmetry of Unanticipated Monetary Policy Shocks}

In general, two prime kinds of asymmetry in the effect of policy shocks on monetary policy targets can be explored. The first asymmetric effect is related to the direction or the sign of the shocks; if the negative shocks affect differently than the positive policy shocks (asymmetry type 1). Additionally, the second asymmetric response is concerned with the effects of the size monetary policy that if the big shocks of monetary actions affect differently compared to the small ones (asymmetry type 2). We utilize NARDL model for shin (2014) which allows us to differentiate between different stances of unanticipated monetary policy (positive or negative) or different sizes (big or small).

\section{A. Exploring the Type 1 asymmetry}

Our aim is exploring the asymmetry in the effect of interest rate shocks in Egypt in terms of the shocks direction. Therefore, monetary policy targets will be modeled on different stances (positive or negative) unanticipated monetary policy shocks. This relationship can be written based on the NARDL in the following form:

$$
\Delta Y_{t}=\delta+\delta_{1} Y_{t-1}+\delta_{2} \varepsilon_{t-1}^{+}+\delta_{3} \varepsilon_{t-1}^{-}+\sum_{k=1}^{p} \phi_{1 k} \Delta Y_{t-k}+\sum_{k=1}^{p} \phi_{2 k} \Delta \varepsilon_{t-k}^{+}+\sum_{k=1}^{p} \phi_{3 k} \Delta \varepsilon_{t-k}^{-}+e_{t}
$$

Where $Y_{t}$ expresses monetary policy goals; GDP and inflation, $\varepsilon_{t}^{+}$is positive unanticipated monetary policy shocks and $\varepsilon_{t}^{-}$is negative shocks. Where:

$$
\begin{aligned}
& \varepsilon_{t}^{+}=\max \left(\varepsilon_{t}, 0\right) \text { otherwise it equals } 0 \\
& \varepsilon_{t}^{-}=\min \left(\varepsilon_{t}, 0\right) \text { otherwise it equals } 0
\end{aligned}
$$

In order to check for the cointegration, we follow Greenwood-Nimmo and Shin(2013) who depend on the cointegration bound test $\left(\mathrm{F}_{\mathrm{pss}}\right)$ of Pesaran et al. (2011). Particularly, the cointegration effect can be tested by testing the null hypothesis $H_{0}: \delta_{1}=\delta_{2}=\delta_{3}=0$. Then, long run expansionary and tight effect of unanticipated shocks also can be explored by $\delta_{2} / \delta_{1}$ and $\delta_{3} / \delta_{1}$ respectively. Furthermore, the likelihood of asymmetric impact of $\varepsilon_{t}^{+}$and $\varepsilon_{t}^{-}$might be checked for the short run and the long run by using the common Wald test.

\section{B. Exploring the type 2 asymmetry}

The target is to explore the asymmetric effect of policy shocks in Egypt in regarding the unanticipated shocks size. Therefore, objective variables will function in different sizes (big or small) of unanticipated monetary policy shocks. This relationship can be written based on the NARDL as following:

$$
\Delta Y_{t}=\gamma+\gamma_{1} Y_{t-1}+\gamma_{2} \varepsilon_{t-1}^{B}+\gamma_{3} \varepsilon_{t-1}^{S}+\sum_{k=1}^{p} \zeta_{1 k} \Delta Y_{t-k}+\sum_{k=1}^{p} \zeta_{2 k} \Delta \varepsilon_{t-k}^{B}+\sum_{k=1}^{p} \zeta_{3 k} \Delta \varepsilon_{t-k}^{S}+u_{t}
$$

Where $Y_{t}$ expresses monetary policy goals; GDP or inflation, $\varepsilon_{t}^{B}$ is big unanticipated monetary policy shocks and $\varepsilon_{t}^{S}$ is small unanticipated monetary policy shocks. Where: 


$$
\begin{aligned}
& \varepsilon_{t}^{B}=\max \left(\varepsilon_{t}, 0\right) \text { if } \varepsilon_{t} \geq 5 \% \text { otherise }=0 \\
& \varepsilon_{t}^{S}=\min \left(\varepsilon_{t}, 0\right) \text { if } \varepsilon_{t} \leq 5 \% \text { otherise }=0
\end{aligned}
$$

The cointegration effect can be tested by testing the null hypothesis $H_{0}: \gamma_{1}=\gamma_{2}=\gamma_{3}=0$. Then, long run effect components of the unanticipated shocks also can be explored by $\gamma_{2} / \gamma_{1}$ and $\gamma_{3} / \gamma_{1}$ respectively. Furthermore, asymmetry of impact $\varepsilon_{t}^{B}$ and $\varepsilon_{t}^{S}$ might be checked by using Wald test.

\section{Data, Empirical Results, and Discussions}

\subsection{Data}

We utilize monthly series from January 2002 to August 2016. Selected sample is set depending on the availability of the Egyptian monthly data. Variables include inflation, real exchange rate, interest rate and industrial production index. The utilized data is captured from IMF's database and Ministry of economic development in Egypt. We take the natural logarithmic form for all included variables excepting for the policy series. Inflation is measured by taking the annual change of the level of Consumer Price Index (CPI). Figure (1) outlines the development of both inflation and interest rate in Egypt during the aforementioned period. We can observe that inflation is highly volatile over the period. However, during the period from January 2007 to the end of 2009 and also during the period from 2012 to 2016 the volatility of inflation is higher than other periods.

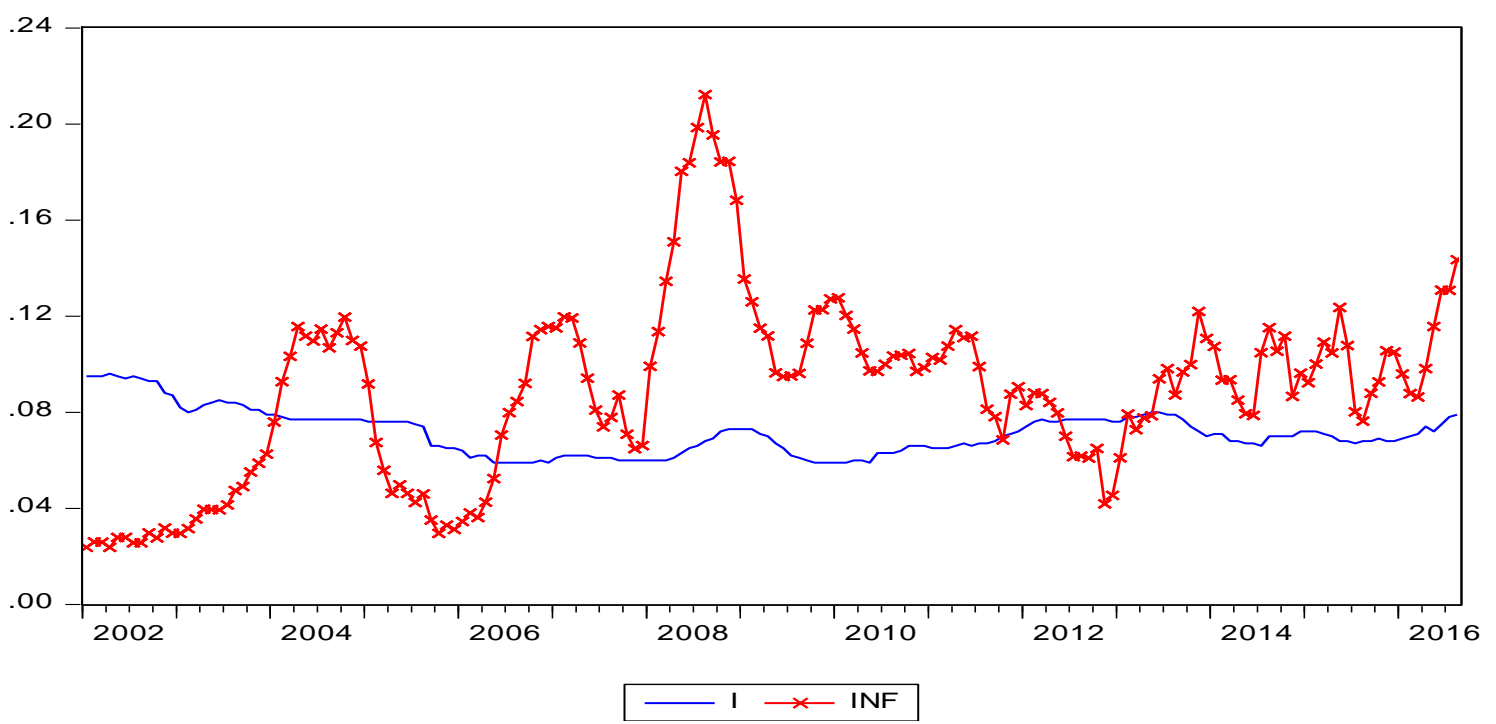

Figure 1. Developments in Monetary Policy Rate and Annual Inflation Rate in Egypt from 2002:01 to 2016:08

Source: International Financial Statistics

Table number (1) depicts stationarity test results of the utilized series. "The Phillip Perron (PP)" and "Augmented Dickey-Fuller (ADF) test" are employed in order to check for the existence of non-stationarity in the series. We can see that exchange rate, annual inflation and GDP are nonstationary then ARDL model is a proper choice as some variables are stationary and others are nonstationary in the level but stationary in the first level.

\subsection{Results and Discussions}

Figure 2 depicts policy shocks over the sample period which captured by the rest of the Taylor rule. This figure shows the nonlinear behavior of these shocks over many points during the period under analysis. Table 2 shows the estimations for Taylor rule. Taylor rule estimated by using ARDL model as the dependent variable is nominal interest rate where dependent variables included inflation, exchange rate, and real production. We can observe that interest rate is considerably reacted to the lag of policy rate, inflation, and exchange rate. In addition, diagnostics tests confirm that there is no economic problem in the estimations.

Table 3 presents the impact of unanticipated policy shocks on the two objective variables based on the traditional ARDL model. Firstly, the bound test indicates that the F-value statistic $=4.289$ with probability 0.000 which means there is a significant cointegration relationship. Also, the cointegration term is significant with a negative value less than one. These results reflect the relationship has stable equilibrium over the long run. The diagnostic tests confirm that there is no any econometric problem for this relationship. Results of the linear case show that the effects of monetary policy for the two targeted variables are only significant for a short run. However, these results are not reliable due to 
the argument that both the increasing and the decreasing monetary policy shocks would not have a similar effect on the real production and inflation. Therefore, we implemented the nonlinear analysis.

Table 4 depicts the results of the asymmetric effect of type 1 for both real production and inflation. We can observe that the cointegration terms are negative and significant in the two equations and the bound test indicates significantly also for the two equations which mean there is substantial cointegration relationship. Diagnostics test show that there are no econometric problems within the model. Results show that: firstly, regarding real production equation, it can be observed that over the long run, changes in real production is significantly affected by its first lag and the first lag of unanticipated policy shocks. Where the probability of the first lag of negative shock is (0.1197) which means it has an insignificant effect. From another side, over the short run, changes in real production are significantly affected by changes in the first and the third lag of the positive unanticipated shocks. However, the probabilities for the changes in negative shocks are around (0.43) which implies that its effect is insignificant. Secondly, regarding inflation equation, over the long run, inflation is significantly affected by its first lag and the changes of first lag of positive policy shocks. For the short run, inflation is significantly affected by changes in its lag and in a lag of positive shocks as well. Moreover, for the two equations in the table 4, the assumption of systematic effect based on the systematic test is refused for inflation and real production over the short run and the long run. As the calculated F statistic is larger than the critical values in all case as depicted by the table 4.

Table 5 shows results for the type 2 asymmetric for both real production and inflation. It is depicted that the cointegration terms in the two equations are negative and significant which implies a stable equilibrium relationship over the long run. Diagnostics tests confirm that there are no econometric problems in the estimations. Estimates reveal that: Firstly, regarding real production equation, over the long run relationship real production is significantly affected by its first lag and the first lag of small policy shocks. Contrary, regarding the short-run effect, real production is considerably determined by changes in its lag and changes in a lag of small changes. On the other hand, for inflation equation, over the long run inflation is determined by its lag and small changes. In addition, for the short run, inflation is significantly affected by changes in its lag and changes in small policy shocks. Furthermore, for the two equations in the table 5, the assumption of systematic effect based on the systematic test is rejected for the two objective variables over the short run and the long run. As the calculated F statistic is larger than the critical levels in all cases as presented in table 5 .

Table 3. Estimates of the Linear ARDL of unanticipated shocks on the two objective variables

\begin{tabular}{|c|c|c|c|}
\hline \multicolumn{2}{|c|}{$\begin{array}{c}\text { Coefficients of monetary shocks in economic production } \\
\text { equation } \mathrm{D}\left(X_{t}\right)\end{array}$} & \multicolumn{2}{|c|}{$\begin{array}{l}\text { Coefficients of monetary shocks in price equation } \\
\mathrm{D}\left(I N F_{t}\right)\end{array}$} \\
\hline \multicolumn{2}{|c|}{$\begin{array}{l}\text { Equation 1 } \\
\end{array}$} & \multicolumn{2}{|c|}{$\begin{array}{l}\text { Equation } 2 \\
\end{array}$} \\
\hline$\Theta$ & $0.490334(0.0042) * * *$ & $\Theta$ & $0.006361 \quad(0.0035)^{* * *}$ \\
\hline$\Theta_{1}$ & $-0.097100(0.0064) * * *$ & $\Theta_{1}$ & $-0.064258(0.0039) * * *$ \\
\hline$\Theta_{2}$ & $\begin{array}{c}1.374946 \\
(0.7864) \\
\end{array}$ & $\Theta_{2}$ & $0.481385(0.4691)$ \\
\hline$\omega_{12}$ & $\begin{array}{c}0.0833 \\
(0.0833)^{*} \\
\end{array}$ & $\omega_{11}$ & $\begin{array}{c}0.369222 \\
(0.0000)^{* * * *} \\
\end{array}$ \\
\hline$\omega_{21}$ & $\begin{array}{c}-0.116941 \\
(0.1174) \\
\end{array}$ & $\omega_{21}$ & $0.850148(0.0643)^{*}$ \\
\hline$\omega_{22}$ & $-9.209442(0.0119)^{* *}$ & $\omega_{22}$ & $\begin{array}{c}-0.697101 \\
(0.1524)\end{array}$ \\
\hline$E C T_{t-1}$ & $-0.098473(0.0050)^{* * *}$ & $E C T_{t-1}$ & $\begin{array}{c}-0.670578 \\
(0.0000) * * *\end{array}$ \\
\hline Wald test & $2.835814(0.0400)^{* *}$ & Wald test & $\begin{array}{c}3.078590 \\
(0.0292) * *\end{array}$ \\
\hline Log-likelihood & 200.0711 & Log-likelihood & 534.0538 \\
\hline F-statistic & $4.289093(0.0002) * * *$ & F-statistic & $7.173552 \quad(0.000) * * *$ \\
\hline D.W & 2.022491 & D.W & 2.0116515 \\
\hline Q-statistic & $\begin{array}{l}5.5578 \\
(0.697) \\
\end{array}$ & Q-statistic & $\begin{array}{l}7.4277 \\
(0.763) \\
\end{array}$ \\
\hline Heteroscedasticity & $\begin{array}{l}1.195131 \\
(0.3087)\end{array}$ & Heteroscedasticity & $1.741931(0.1280)$ \\
\hline Serial correlation & $\begin{array}{c}2.098677 \\
(0.1261) \\
\end{array}$ & Serial correlation & $1.940799(0.1470)$ \\
\hline Ramsey reset & $\begin{array}{l}0.764354 \\
(0.3833) \\
\end{array}$ & Ramsey reset & $2.104565(0.1488)$ \\
\hline
\end{tabular}


*** reflects the coefficient is significant with probabilities $1 \%, 5 \%, 10 \%$; ** the coefficient is significant with probabilities $5 \%, 10 \%$; * the coefficient is significant with probability $10 \%$.

Table 4. Asymmetric type 1 coefficients of shocks in real production and inflation equations

\begin{tabular}{|c|c|c|c|}
\hline \multirow{2}{*}{\multicolumn{2}{|c|}{$\begin{array}{c}\text { Coefficients of monetary shocks in economic production } \\
\text { equation } \mathrm{D}\left(X_{t}\right) \\
\text { Equation } 1\end{array}$}} & \multirow{2}{*}{\multicolumn{2}{|c|}{$\begin{array}{l}\text { Coefficients of monetary shocks in price equation } \\
\qquad \mathrm{D}\left(I N F_{t}\right) \\
\text { Equation } 2 \\
\end{array}$}} \\
\hline & & & \\
\hline$\delta$ & $\begin{array}{c}0.428031 \\
(0.0048) * * *\end{array}$ & $\delta$ & $\begin{array}{c}0.006676 \\
(0.0094) * * *\end{array}$ \\
\hline$\delta_{1}$ & $\begin{array}{c}-0.082234 \\
(0.0064) * * *\end{array}$ & $\delta_{1}$ & $\begin{array}{c}-0.055947 \\
(0.0083)^{* * *}\end{array}$ \\
\hline$\delta_{2}$ & $\begin{array}{c}13.54222 \\
(0.0441)^{* *}\end{array}$ & $\delta_{2}$ & $\begin{array}{l}-2.511821 \\
(0.0184)^{* *}\end{array}$ \\
\hline$\delta_{3}$ & $\begin{array}{c}-17.44242 \\
(0.1197) \\
\end{array}$ & $\delta_{3}$ & $\begin{array}{c}-0.090125 \\
(0.9605) \\
\end{array}$ \\
\hline$\phi_{11}$ & $\begin{array}{c}-0.116941 \\
(0.1174)\end{array}$ & $\phi_{11}$ & $\begin{array}{c}0.377144 \\
(0.0000)^{* * *}\end{array}$ \\
\hline$\phi_{21}$ & $\begin{array}{l}15.11626 \\
(0.0578)^{*} \\
\end{array}$ & $\phi_{21}$ & $\begin{array}{c}3.026420 \\
(0.0074)^{* * *}\end{array}$ \\
\hline$\phi_{23}$ & $\begin{array}{l}-0.116941 \\
(0.0035)^{* *}\end{array}$ & $\phi_{24}$ & $\begin{array}{c}1.481524 \\
(0.1618)\end{array}$ \\
\hline$\phi_{31}$ & $\begin{array}{c}-3.749408 \\
(0.4337)\end{array}$ & $\phi_{31}$ & $\begin{array}{c}1.288896 \\
(0.3163)\end{array}$ \\
\hline$E C T_{t-1}$ & $\begin{array}{c}-0.082213 \\
(0.0068) * * *\end{array}$ & $E C T_{t-1}$ & $\begin{array}{c}-0.053484 \\
(0.0096) * * *\end{array}$ \\
\hline Cointegration & $\begin{array}{c}3.179475 \\
(0.0151)^{* *}\end{array}$ & Cointegration & $\begin{array}{c}2.654467 \\
(0.0350)^{* *}\end{array}$ \\
\hline Symmetric test short run & $\begin{array}{c}4.5664 \\
(0.03)^{* *}\end{array}$ & Symmetric test short run & $\begin{array}{c}8.836 \\
(0.003) * * *\end{array}$ \\
\hline Symmetric test long run & $\begin{array}{c}4.21 \\
(0.04)^{* *}\end{array}$ & Symmetric test long run & $\begin{array}{c}4.941 \\
(0.0276)^{* * *}\end{array}$ \\
\hline Log-likelihood & 210.8787 & Log-likelihood & 556.3094 \\
\hline F-statistic & $\begin{array}{c}4.427048 \\
(0.000157)^{* * *}\end{array}$ & F-statistic & $\begin{array}{c}4.468478 \\
(0.000015)^{* * *}\end{array}$ \\
\hline D.W & 2.006756 & D.W & 2.080250 \\
\hline Q-statistic & $\begin{array}{l}17.190 \\
(0.102)\end{array}$ & Q-statistic & $\begin{array}{l}3.7999 \\
(0.956)\end{array}$ \\
\hline Heteroscedasticity & $\begin{array}{c}0.162942 \\
(0.6870)\end{array}$ & Heteroscedasticity & $\begin{array}{c}1.550168 \\
(0.1263)\end{array}$ \\
\hline Serial correlation & $\begin{array}{c}0.917853 \\
(0.4014)\end{array}$ & Serial correlation & $\begin{array}{c}1.047799 \\
(0.3531) \\
\end{array}$ \\
\hline Ramsey reset & $\begin{array}{l}2.696123 \\
(0.1025)\end{array}$ & Ramsey reset & $\begin{array}{c}0.849501 \\
(0.3581)\end{array}$ \\
\hline
\end{tabular}

*** reflects the coefficient is significant with probabilities $1 \%, 5 \%, 10 \%$; ** the coefficient is significant with probabilities $5 \%, 10 \%$; * the coefficient is significant with probability $10 \%$. 
Table 5. Asymmetric type 2 coefficients of shocks in real production and inflation equations

\begin{tabular}{|c|c|c|c|}
\hline \multirow{2}{*}{\multicolumn{2}{|c|}{$\begin{array}{c}\text { Coefficients of monetary shocks in economic production } \\
\text { equation } \mathrm{D}\left(X_{t}\right)\end{array}$}} & \multirow{2}{*}{\multicolumn{2}{|c|}{$\begin{array}{l}\text { Coefficients of monetary shocks in price equation } \\
\mathrm{D}\left(I N F_{t}\right) \\
\text { Equation } 2\end{array}$}} \\
\hline & & & \\
\hline$\gamma$ & $\begin{array}{c}0.447520 \\
(0.0070)^{* * *} \\
\end{array}$ & $\gamma$ & $\begin{array}{c}0.005816 \\
(0.0039) * * *\end{array}$ \\
\hline$\gamma_{1}$ & $\begin{array}{c}-0.088178 \\
(0.0075)^{* * *}\end{array}$ & $\gamma_{1}$ & $\begin{array}{c}-0.058144 \\
(0.0058)^{* * *}\end{array}$ \\
\hline$\gamma_{2}$ & $\begin{array}{c}0.095276 \\
(0.4066) \\
\end{array}$ & $\gamma_{2}$ & $\begin{array}{c}0.013106 \\
(0.1363) \\
\end{array}$ \\
\hline$\gamma_{3}$ & $\begin{array}{l}-0.1109 \\
(0.0508)^{*}\end{array}$ & $\gamma_{3}$ & $\begin{array}{c}-0.063714 \\
(0.0032) * * *\end{array}$ \\
\hline$\zeta_{11}$ & $\begin{array}{c}-0.200092 \\
(0.0085)^{* * *}\end{array}$ & $\zeta_{11}$ & $\begin{array}{c}0.35289 \\
(0.000)^{* * *}\end{array}$ \\
\hline$\zeta_{21}$ & $-0.106070(0.2996)$ & $\zeta_{21}$ & $\begin{array}{c}-0.008408 \\
(0.1621) \\
\end{array}$ \\
\hline$\zeta_{22}$ & $-0.108280(0.2073)$ & $\zeta_{31}$ & $\begin{array}{c}0.064108 \\
(0.0038) * * *\end{array}$ \\
\hline$\zeta_{31}$ & $0.213726(0.0470)^{* *}$ & $\zeta_{33}$ & $\begin{array}{c}-0.016212 \\
(0.2770)\end{array}$ \\
\hline$E C T_{t-1}$ & $\begin{array}{c}-0.085629 \\
(0.0055)^{* * *}\end{array}$ & $E C T_{t-1}$ & $\begin{array}{c}-0.055966 \\
(0.0061)^{* * *}\end{array}$ \\
\hline Cointegration & $\begin{array}{c}3.543649 \\
(0.0085)^{* * * *}\end{array}$ & Cointegration & $\begin{array}{c}3.060973 \\
(0.0184)^{* *}\end{array}$ \\
\hline Symmetric test short run & $\begin{array}{c}5.059 \\
(0.0259) * *\end{array}$ & Symmetric test short run & $\begin{array}{c}10.25 \\
(0.001)^{* * * *}\end{array}$ \\
\hline Symmetric test long run & $\begin{array}{c}3.80 \\
(0.052)^{*}\end{array}$ & Symmetric test long run & $\begin{array}{c}0.29 \\
(0.587) \\
\end{array}$ \\
\hline Log-likelihood & 199.4651 & Log-likelihood & 543.1366 \\
\hline F-statistic & $2.9625(0.00197) * * *$ & F-statistic & $\begin{array}{c}6.412985 \\
(0.00000)^{* * *}\end{array}$ \\
\hline D.W & 2.013236 & D.W & 2.08468 \\
\hline Q-statistic & $\begin{array}{l}11.505 \\
(0.402)\end{array}$ & Q-statistic & $7.5306(0.755)$ \\
\hline Heteroscedasticity & $\begin{array}{c}1.344249 \\
(0.2119)\end{array}$ & Heteroscedasticity & $\begin{array}{l}1.728646 \\
(0.1058)\end{array}$ \\
\hline Serial correlation & $\begin{array}{l}1.145508 \\
(0.3208) \\
\end{array}$ & Serial correlation & $\begin{array}{l}1.286492 \\
(0.2791) \\
\end{array}$ \\
\hline Ramsey reset & $\begin{array}{c}0.201859 \\
(0.6539)\end{array}$ & Ramsey reset & $\begin{array}{c}0.704270 \\
(0.4026)\end{array}$ \\
\hline
\end{tabular}

$* * *$ reflects the coefficient is significant with probabilities $1 \%, 5 \%, 10 \%$; ** the coefficient is significant with probabilities $5 \%, 10 \%$; * the coefficient is significant with probability $10 \%$.

\section{Conclusion and Policy Recommendations}

In general, it is be assumed that the central bank loss function is quadratic in inflation and real production and then this function is minimized with the assumption of the linear environment of the economy. However, the central bank seems to treat positive and negative deviations differently. Implications of the asymmetric effect of monetary policy might be significant for conducting this critical policy. Augmenting the asymmetric items of monetary policy inside the central bank's reaction function might enrich information for policymakers and also might bring answers for many questions about the effectiveness and the behavior of this policy. Further, this could improve the modeling process and increase the accuracy of predictions.

This study tried to answer the question whether the response of inflation and real production for the unanticipated shock of monetary policy is asymmetric or symmetric in Egypt. The shocks analyzed using residual component of the Taylor rule. Then, we explored the asymmetric effect of unexplored monetary policy shocks regarding the direction and the size of the shocks. Results showed that firstly, residuals of monetary policy rule depicted some non-linearity. Thus there is a need to explore the asymmetric in the effect of those shocks on the objectives of the monetary policy. Secondly, regarding the direction of shocks, it is concluded that the response of the two objective variables is significantly determined by only positive shocks where these responses did not receive a reliable effect by negative unanticipated 
policy shocks. Thirdly, regarding the value of unanticipated shocks, our results show that the small unexpected monetary policy shocks have significant effect where the big unexpected monetary policy shocks do not.

Our primary policy recommendation is that policymakers should take into consideration asymmetry of monetary policy when design policies. Small and positive monetary shocks are more useful for affecting the policy targets. Future research might focus on exploring the asymmetric effect of other policies like fiscal policy.

\section{References}

Akbar, K., Mostafa, S., \& Razieh, A. (2012). Asymmetric effects of monetary shocks on economic growth \& inflation: a case study in Iran. International Journal of Business and Social Science, 3(9). https://doi.org/10.1080/13504851.2015.1073836

Aye, G. C., \& Gupta, R. (2012). Are the effects of monetary policy asymmetric in India? evidence from a nonlinear Vector Autoregression Approach, Working Papers 2012-02, Department of Economics, University of Pretoria. https://doi.org/10.3923/tasr.2012.565.571

Barro, R. (1978). Unanticipated money, output, and the price level in the United States. Journal of Political Economy, 86, 549-580. https://doi.org/10.1086/260699

Cheng, J. (2018). The Asymmetric Effects of Monetary Policy on Stock Market. Quarterly Journal of Finance, 8(01). https://doi.org/10.1142/S2010139218500088

Christian, M., \& Regis, B. (2015). Measuring the non-linear effects of monetary policy, 2015 Meeting Papers, 49, Society for Economic Dynamics. https://doi.org/10.1080/13504851.2015.1073836

Clausen, V., \& Hayo, B. (2002). Asymmetric monetary policy effects in EMU. ZEI Working Papers B 04-2002, Center for European Integration Studies, University of Bonn. https://doi.org/10.1080/00036840600581497

Cover, J. P. (1992). Asymmetric effects of positive and negative money-supply shocks. Quarterly Journal of Economics, 107, 1261-1282. https://doi.org/10.2307/2118388.

Cukierman, A., \& Muscatelli, A. (2008). Nonlinear Taylor rules and asymmetric preferences in Central Banking: Evidence from the United Kingdom and the United States. The B.E. Journal of Macroeconomics, No.8/1, Article 7. https://doi.org/10.2202/1935-1690.1488

Doaa, A. A., \& Mamdouh, A. M. A. (2018). Inflation instability impact on interest rate in Egypt: augmented Fisher hypothesis test. Applied Economics and Finance, 5(1). https://doi.org/10.11114/aef.v5i1.2709

Dolado, J. J., \& Mar'ia, D. R. (2006). Chapter 12 State asymmetries in the effects of monetary policy shocks on output: Some new evidence for the euro-area. In P. R. Costas Milas and D. van Dijk (Eds.), Nonlinear Time Series Analysis of Business Cycles, Volume 276 of Contributions to Economic Analysis, pp. 311 - 331. Elsevier. https://doi.org/10.1016/S0573-8555(05)76012-0

Dolado, J. R. M. D. P., \& Ruge, M. F. J. (2004). Non-linear monetary policy rules: Some new evidence for the U.S. Studies in Nonlinear Dynamics \& Econometrics 8, 3(2). https://doi.org/10.2202/1558-3708.1155.

Felix, S. N. (2018). Testing for asymmetric central bank preferences. International Journal of Economics and Finance, 10(4). DOI: https://doi.org/10.5539/ijef.v10n4p25

Friedman, B. (1995). Does monetary policy affect real economic activity? Why do we still ask this question?. NBER Working Paper, 5212. https://doi.org/10.3386/w5212

Greenwood, N. M., \& Shin, Y. (2013). Taxation and the asymmetric adjustment of selected retail energy prices in the UK. Economics Letters, 121, 411-416. https://doi.org/10.1016/j.econlet.2013.09.020

Jeevan, K. K. (2017). Examining the asymmetric impact of monetary policy in india. The Journal of Applied Economic Research, 11(3), 290-314. https://doi.org/10.1177/0973801017703500.

Karras, G., \& Houston, H. S. (1999). Why are the effects of money supply shocks symmetric? evidence from prices, consumption, and investment. Journal of Macroeconomics, No21. https://doi.org/10.1016/S0164-0704(99)80003-2

Karras, K. (1996). Why are the effects of money-supply shock Asymmetric? Convex aggregate supply or pushing on a string. Journal of Macroeconomics, 18(4), 605-619. https://doi.org/10.1016/S0164-0704(96)80054-1

Kilian, L., \& Vigfusson, R. J. (2011). Are the responses of the U.S. economy asymmetric in energy price increases and decreases?. Quantitative Economics, 2(3), 419-453. https://doi.org/10.3982/QE99

Laxton, D., Rose, D., \& Tambakis, D. (1999). The U.S. Phillips curve: The case for asymmetry. Journal of Economic Dynamics and Control, 23, 1459-1485. https://doi.org/10.1016/S0165-1889(98)00080-3

Lucas, R E. J. (1996). Nobel lecture monetary neutrality. Journal of Political Economy, 104, 661-682. 
https://doi.org/10.1086/262037

Mamdouh, A. M. A. (2017). Improving Phillips Curve's inflation forecasts under misspecification. Journal for Economic Forecasting, Institute for Economic Forecasting, O(3), pages 54-76, September. www.ipe.ro/rjef/rjef3_17/rjef3_2017p54-76

Maurice, O. (2018). Can accommodative monetary policies help explain the productivity slowdown?. IMF Economic Counsellor and Director of Research, January 10.

Midrigan, V., \& Daniel, X. (2014) . Finance and Misallocation: Evidence from Plant-Level Data. American Economic Review, 104(2), 422-458. https://doi.org/10.1257/aer.104.2.422

Morgan, D. (1993). Asymmetric effects of monetary policy. Federal Reserve Bank of Kansas City Economic Review, 78, 21-33.

Mustafa, C., \& Ozge, K. K., \& Kostas, M. (2017). The role of financial depth on the asymmetric impact of monetary policy. Oxford Bulletin of Economics and Statistics, 79(6), 0305-9049. https://doi.org/10.1111/obes.12160

Olumuyiwa, A. (2017). Asymmetry effects of monetary policy shocks on output in Nigeria: A Non-Linear Autoregressive Distributed Lag (NARDL) Approach. Economics Society of South Africa Biennial conference.

Paul, A. (1998). Identifying the asymmetric effects of monetary policy on output for the UK. Dept of Economic. The University of Strathclyde.

Pesaran, M. H., Shin, Y., \& Smith, R. J. (2001). Bounds Testing Approaches to the analysis of level relationships. J. Appl. Econometrics, 16(3), 289-326. https://doi.org/10.1002/jae.616

Phelps, E. S. (1968). Money-wage dynamics and labor market equilibrium. Journal of Political Economy, 76, 678-711. https://doi.org/10.1086/259438

Phil, B. (2006). Are the effects of monetary policy asymmetric in Australia?, MRG Discussion Paper Series 0406, School of Economics, University of Queensland, Australia. https://doi.org/10.1080/00343404.2012.714897

Pierre, R. (2001). Asymmetric effects of monetary policy shocks. The World Bank Washington DC 20433. https://doi.org/10.1080/13504851.2015.1073836

Pyhtia, I. (1999). The nonlinearity of the Phillips curve and European monetary policy. Bank of Finland Discussion Papers, No.17/1999.

Ravn, M. O., \& Sola, M. (1996). A reconsideration of the empirical evidence on the asymmetric effect of money supply shocks: positive vs. negative or big vs. small? Unpublished manuscript, University of Aarhus, Denmark. https://doi.org/10.2139/ssrn.56134

Ravn, M. O., \& Sola, M. (2004). Asymmetric effects of monetary policy in the United States. Federal Reserve Bank of St. Louis Review, 86(5), 41-60. https://doi.org/10.20955/r.86.41

Rhee, W., \& Rich, R. (1995). Inflation and the asymmetric effects of money on output fluctuations. Journal of Macroeconomics, 14(4), 683-702. https://doi.org/10.1016/0164-0704(95)80089-1

Sensier, M., D. R. O., \& Ocal, N. (2002). Asymmetric interest rate effects for the UK real economy. Oxford Bulletin of Economics and Statistics, 64(4), 315-339. https://doi.org/10.1111/1468-0084.00028

Shen, C. H. (2000). Are the effects of monetary policy asymmetric? The case of Taiwan. Journal of Policy Modelling 22(2), 197-218. https://doi.org/10.1016/S0161-8938(98)00025-8

Shin, Y., B. C. Y., \& Greenwood, N. M. (2014). Modelling asymmetric cointegration and dynamic multipliers in a nonlinear ARDL framework. Festschrift in Honor of Peter Schmidt: Econometric Methods and Applications, eds. By R. Sickels and W. Horrace: Springer, 281-314. https://doi.org/10.2139/ssrn.1807745

Vlieghe, G. (2017). Good policy vs accurate forecasts. Speech at Bloomberg Headquarters, London. https://www.olverisk.com/single-post/2017/04/05/Good-policy-vs-accurate-forecasts-1.

Volkan, \& Hakan. (2015). Asymmetric effects of monetary policy shocks on economic performance: empirical evidence from Turkey. Applied Economics Letters, 23(5), 353-360. https://doi.org/10.1080/13504851.2015.1073836

Weise, C. (1999). The asymmetric effects of monetary policy: A nonlinear vector autoregression approach. Journal of Money, Credit and Banking, 31(1), 85-108. https://doi.org/10.2307/2601141 


\section{Appendix}

Table 1. Unit root statistics

\begin{tabular}{l|l|l|l|l}
\hline & \multicolumn{3}{|c|}{ Level } & First Difference \\
\hline & ADF & PP & ADF & PP \\
\hline INF & 0.0776 & 0.0771 & 0.0000 & 0.0000 \\
\hline I & 0.0364 & 0.0663 & 0.0000 & 0.0000 \\
\hline GDP & 0.8752 & 0.8877 & 0.0000 & 0.0000 \\
\hline Exr & 0.0704 & 0.1009 & 0.0000 & 0.0000 \\
\hline
\end{tabular}

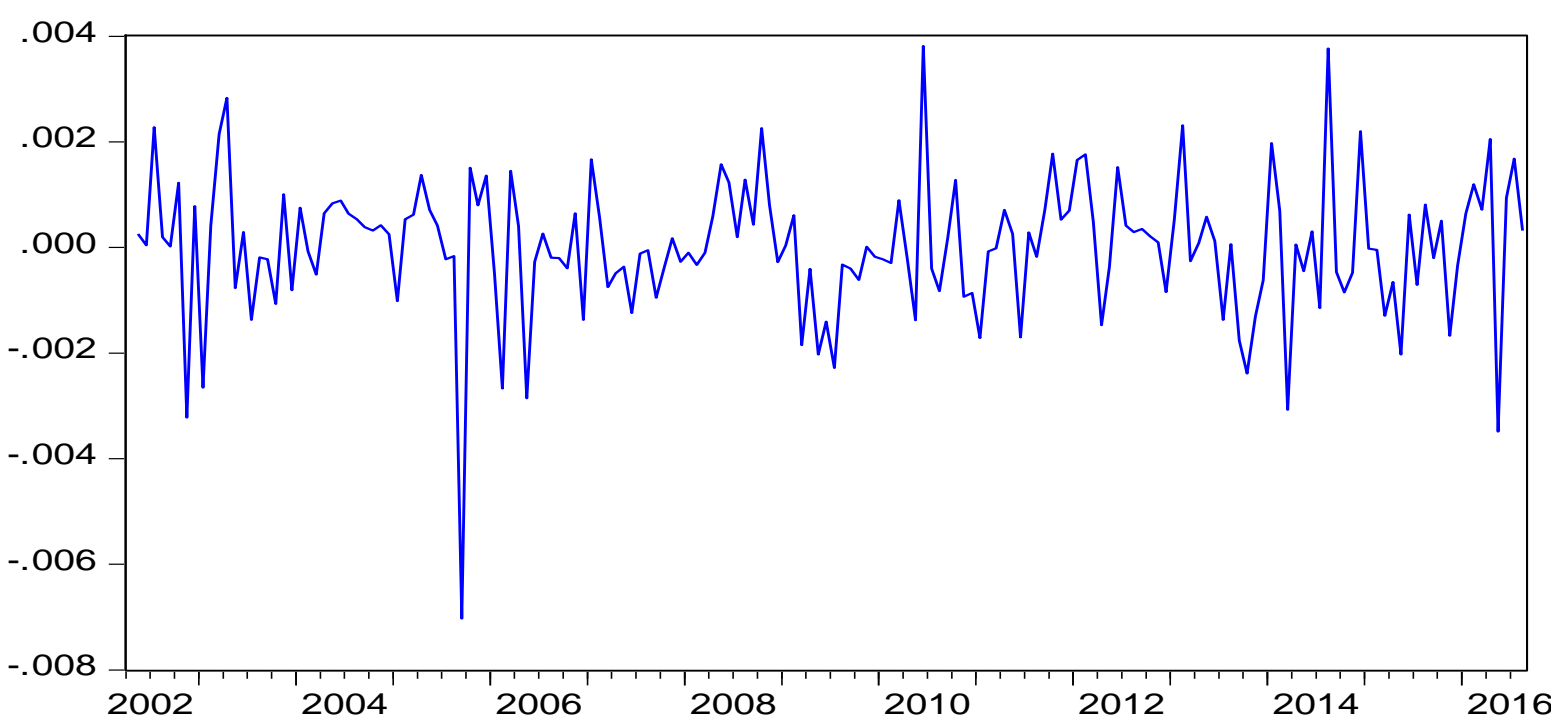

Figure 2. Estimated Unanticipated Shocks of Monetary Policy

Table 2. Taylor estimation results

\begin{tabular}{c|c}
\hline$\alpha$ & $-0.001787(0.8103)$ \\
\hline$\alpha_{1}$ & $0.186751(0.0147)^{* *}$ \\
\hline$\alpha_{2}$ & $0.000771(0.3030)$ \\
\hline$\alpha_{3}$ & $0.007877(0.0261)^{* *}$ \\
\hline$\alpha_{4}$ & $0.012985(0.0147)^{* *}$ \\
\hline$\beta_{11}$ & $-0.186751(0.0147)^{* *}$ \\
\hline$\beta_{21}$ & $0.000771(0.3030)$ \\
\hline$\beta_{31}$ & $0.007877(0.0261)^{* *}$ \\
\hline$\beta_{41}$ & $-0.012985(0.0147)^{* *}$ \\
\hline$E C T_{t-1}$ & $-0.706758(0.0000)^{* * *}$ \\
\hline Log-likelihood & 896.4232 \\
\hline F-statistic & $4.929116(0.0000)^{* * *}$ \\
\hline D.W & 2.054569 \\
\hline Q-statistic & $7.7148(0.807)$ \\
\hline Heteroscedasticity & $0.825857(0.5932)$ \\
\hline Serial correlation & $0.705181(0.4955)$ \\
\hline Ramsey reset & $0.092928(0.7609)$ \\
\hline &
\end{tabular}

\section{Copyrights}

Copyright for this article is retained by the author(s), with first publication rights granted to the journal.

This is an open-access article distributed under the terms and conditions of the Creative Commons Attribution license which permits unrestricted use, distribution, and reproduction in any medium, provided the original work is properly cited. 